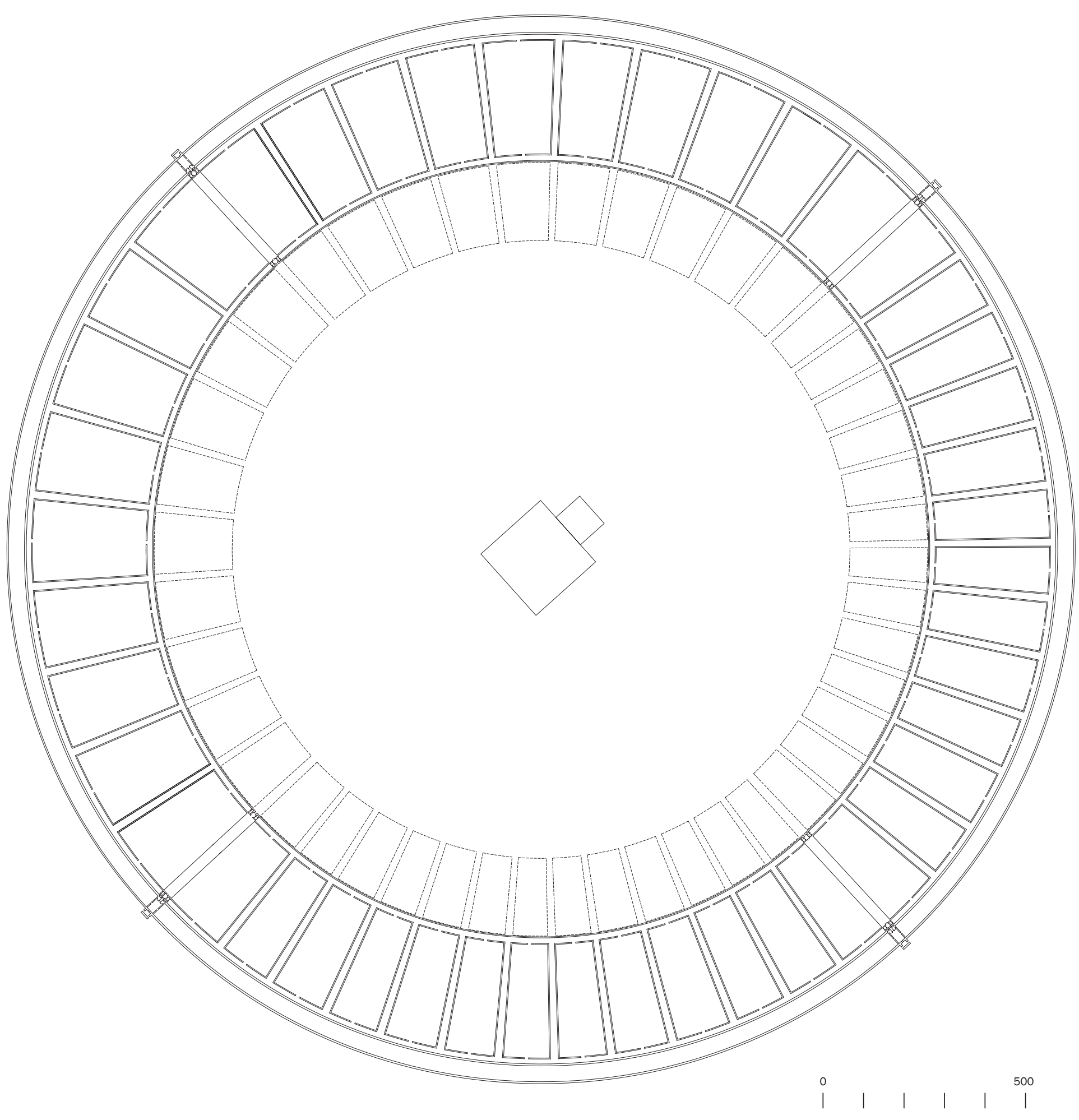




\title{
LAS MIL Y UNA BAGHDAD DE AL-MANSUR
}

\author{
Martino Tattara \\ Profesor, Berlage Institute \\ Una instrucción legible -como las que escribía Sol Lewitt- deja en evidencia el poder de las memorias de arquitectura en cuanto \\ representación: una matriz de diseño descrita con el rigor de la palabra puede garantizar la vitalidad y la supervivencia de los principios \\ rectores de un proyecto. \\ Palabras clave: Urbanismo - Irak, ciudades persas, historia del urbanismo, planificación, levantamiento.
}

$\mathbf{U}$ na vez más, los proyectos para la fundación de nuevas ciudades están en el centro de la discusión arquitectónica. En las últimas décadas hemos sido testigos del surgimiento de numerosas ciudades en los países del este de Asia y las noticias sobre nacientes ciudades construidas desde cero se suceden, con inmutable entusiasmo, hasta hoy. En 2001, el Ministro de Asuntos Civiles de China hizo pública su ambición de completar la construcción de cuatrocientas nuevas ciudades hacia el año 2020, de modo de dar residencia a numerosos inmigrantes del campo y estimular el proceso de industrialización nacional en curso.

En Medio Oriente, la reciente explosión urbana ha ido a la par con el desarrollo de ambiciosos proyectos para construir nuevas ciudades, los que han acaparado la atención de los medios especializados principalmente por la incorporación de algunos starchitects en su diseño. Por otra parte, la reciente celebración del aniversario número 50 de la inauguración de Brasilia atrajo nuevamente las miradas hacia algunas experiencias -a menudo desatendidas- ocurridas en la historia de la arquitectura y el urbanismo modernos, consideradas por la historiografía dominante como poco más que ejemplos nítidos del fracaso de las utopías del siglo xx.

Aunque sería necesario hacer una distinción entre aquellos proyectos que han sido capaces de ampliar la noción de ciudad -o que están apostando a una renovación de la idea de urbanidad- respecto de otros que simplemente replican paradigmas preexistentes, seleccionando desde la historia de la arquitectura algunas referencias relevantes, una mirada detenida al conjunto de estos emprendimientos deja de manifiesto que diseñar una ciudad desde cero es, en realidad, no solo una tarea inusual que unos pocos arquitectos abordan durante sus carreras profesionales. Se trata de un ejercicio de diseño sin duda equivalente al mayor reto arquitectónico, uno en el cual el alcance, el potencial y los límites de la disciplina son llevados hasta el extremo, poniendo a prueba la capacidad operativa de los instrumentos propios del trabajo del arquitecto.

El proyecto de una ciudad es un oxímoron. Imposible en sus propios términos, en él el rol del arquitecto está necesariamente limitado al establecimiento de aquellos principios formales, tipológicos o incluso normativos que probarán en el tiempo ser capaces de orientar y controlar el desarrollo de la ciudad. Primero y antes que todo, el proyecto de una ciudad es -en contraste con la magnitud y el alcance del esfuerzo asociado- un asunto vinculado a la reducción, a las restricciones y a las limitaciones.

El crítico uruguayo Ángel Rama produjo un ensayo notable sobre el poder de la palabra escrita en la formación de las sociedades latinoamericanas, donde explora el rol fundamental de los "hombres letrados" para entender lo que él considera un aspecto crucial de la ciudad colonial latinoamericana. Según su libro La ciudad letrada, la principal característica de la urbe colonial no es la aplicación de una grilla como principio elemental de la fundación de ciudades, sino más bien el rigor sostenido en la descripción por escrito de los principios rectores que se suponían capaces de orientar la composición del espacio urbano. En Latinoamérica, esto se habría llevado a un punto de refinamiento tal que el orden técnico puede, consecuentemente, reproducir y confirmar el orden social de la manera en que este es establecido por el proyecto.

Ese intento por destilar lo esencial y descartar lo superfluo es confirmado por otro proyecto capital: el plan piloto de Brasilia (1956-1960). En el caso de la nueva sede del poder político brasileño, el arquitecto no ganó el concurso solo gracias a la claridad de sus dibujos: fue clave el texto de la memoria, el célebre "relatorio". En él, los escuetos principios formales y organizacionales del proyecto (como el uso de la supercuadra como principal solución para las áreas residenciales) fueron descritos con tal nitidez y precisión que el profesional aseguró su legibilidad para los ejecutores que luego se encargarían de levantar la ciudad.

La misma actitud reduccionista caracteriza el proyecto de la gran ciudad levantada por el califa Al-Mansur en el sitio de Baghdad, la célebre y misteriosa ciudad circular cuya construcción se inició en el año 762 d.C. y de la cual no existen restos arqueológicos. La planta de la ciudad ha sido objeto de reconstrucciones históricas basadas en unas pocas fuentes bibliográficas disponibles -como La historia de Baghdad escrita por Khatib Al-Badhdadi (1071) y Geografía de Ya'qubi's- y desarrolladas primordialmente por K.A.C. Creswell, quien en su Compendio de arquitectura paleoislámica (1958) entregó una primera interpretación posible de la planta de la ciudad, y Jacob Lassner en La topografía de Bagdad en las edades medias tempranas (1970).

Aunque la Baghdad de Al-Mansur no es de ninguna forma la primera ciudad circular construida en la historia de la humanidad, puede considerarse uno de los ejemplos más destacados de planificación urbana en el mundo del Islam. En términos generales, la ciudad se presentaba como un anillo con una circunferencia de 16.000 cubits $^{1}$ (alrededor de $8,3 \mathrm{~km}$ ) y 5.093 cubits de diámetro, equivalentes a $2,6 \mathrm{~km}$. Sin embargo, a diferencia de los esquemas circulares típicos del pensamiento renacentista, en que el círculo era usado para comunicar "la jerarquía social proyectada por el

1 El cubit es una antigua unidad de medida de longitud que aproximadamente equivale al largo de un antebrazo. Creswell sugiere una medida de $51,8 \mathrm{~cm}$. 
planificador, con los edificios de gobierno situados al centro y áreas residenciales asignadas a diferentes clases sociales en anillos concéntricos, desde el centro a la periferia" (Rama, 1996), en el caso de la Baghdad de Al-Mansur se trataba de nada más que una estructura habitable de ancha crujía, que delimitaba un enorme vacío circular -la gran Rahaba- en el centro del cual se ubicaba el palacio del califa, junto a la mezquita. La radicalidad de su esquema urbano no proviene de la utilización de una figura geométrica abstracta que, como Creswell sugiere, puede de hecho encontrarse varias veces en otras ciudades del mundo islámico, partiendo por los campamentos militares asirios. Más bien, se vincula al intento de implementar la posibilidad de una ciudad por el proyecto de su borde: un macizo muro habitable de múltiples capas, una fortaleza que simultáneamente contenía y organizaba funciones de vivienda, defensa y comunicación.

Las dos principales reconstrucciones de la planta de la ciudad, propuestas respectivamente por Creswell y Lassner, formulan la misma organización para el elemento fundante, lineal y circular. La sección tipo del anillo está caracterizada por series de cinco muros concéntricos que forman tres caminos interiores igualmente circulares -señalados como el primer, segundo y tercer fasil- que corren ininterrumpidamente desde una puerta de la ciudad a la otra. Estas son cuatro, cada una equidistante de la anterior y nombradas según la provincia o ciudad hacia la cual se dirigen; van cortando cada fasil e interrumpiendo, en consecuencia, la continuidad del tráfico en ellos. Además de proveer accesibilidad general a la ciudad, las cuatro puertas organizan la distribución entre los diversos sectores de vivienda, facilitan los intercambios entre los tres anillos concéntricos y permiten la penetración hacia el gran patio circular. Cada acceso está -comenzando desde el muro exteriororganizado como una secuencia espacial lineal que empieza con el cruce sobre la zanja que corre a lo largo del muro exterior de la ciudad, atraviesa un primer patio, luego dos portones separados por un estrecho corredor, un largo y amplio portal diseñado para albergar a unos mil guardias, un pequeño patio que interrumpe el tercer fasil y, finalmente, el muro interior. La definición de una ciudad a partir de la descripción de un único elemento, como testimonian las reconstrucciones de Creswell y Lassner, confirma que para diseñar una ciudad es necesaria una actitud reduccionista. Mientras Creswell sostiene que al final de la secuencia de acceso, después de la última bóveda, uno se encontraría en medio de un patio cuadrado de 20 cubits que conduciría directamente a la gran plaza central, Lassner sugiere que "rodeando el vacío central estaban las habitaciones de los hijos menores de Al-Mansur, sus sir- vientes residentes, los esclavos, el tesoro, el arsenal, el diwan de la corte, las cocinerías y varias otras dependencias del Estado". Según esa hipótesis existiría entonces un anillo de edificios entre el tercer fasil y la explanada central (Allan, 1991). La posible construcción de un anillo habitado en torno al vacío principal revela que todo el proyecto urbano era, esencialmente, una sencilla estructura de muros que servían como soporte al proceso de formación de la ciudad. Cada fasil y las cuatro grandes puertas corresponderían a los elementos de infraestructura mayor de la ciudad, actuando como soporte, sirviendo a las áreas destinadas a funciones residenciales y también orientando el eventual crecimiento urbano. La existencia de un anillo interno es, en definitiva, un asunto irrelevante en la medida en que su existencia se interprete como el resultado natural de la concepción urbana misma: un esqueleto sobre el cual el cuerpo urbano se va desarrollando. Vistas así, nunca fue posible realizar por completo el proyecto de la Baghdad de Al-Mansur ni la consiguiente reconstrucción de su planta. Y nunca lo será, mientras la naturaleza de la propia ciudad se sostenga en el control y diseño de unos pocos aspectos -las puertas de acceso, los rituales de entrada, las maneras de desplazarse por la trama urbana, los largos muros-, y el resto parezca estar abierto a una multiplicidad de interpretaciones y eventos.

Los dibujos que acompañan a este texto ofrecen algunos desarrollos posibles desde este radical plan urbano, en un intento de visualizar los resultados que pueden producir estos principios formales y esta actitud frente al diseño. ARQ

Martino Tattara Arquitecto, Università IUAV di Venezia, 2002; Master of Architecture, Berlage Institute Rotterdam, 2005 y PhD, Università IUAv di Venezia, 2008. La relación entre la arquitectura y los proyectos urbanos de gran escala es el tema central de su trabajo como teórico. Su tesis doctoral abordó el proyecto de Lucio Costa para Brasilia y ha sido ampliamente publicada y expuesta en conferencias vinculadas al diseño urbano. Co-fundador del estudio de arquitectura Dogma, actualmente enseña en Artesis University College de Antwerp y en Berlage Institute, donde también es responsable de algunos proyectos externos.

\section{Bibliografía}

ALLAN, James W. "New Additions to the New Edition". En Muqarnas 8. The Aga Khan Program for Islamic Architecture, Harvard University y Massachusetts Institute of Technology, Cambridge, 1991, p. 17.

CRESWELL, K.A.C. A Short Account of Early Muslim Architecture. Penguin Books, Harmondsworth, 1958.

LASSNER, Jacob. The Topography of Baghdad in the Early Middle Ages. Wayne State University Press, Detroit, 1970

RAMA, Angel. The Lettered City. Duke University Press, Durham, NC, 1996. 
THE MULTIPLICITY OF AL MANSUR'S

BAGHDAD

Martino Tattara

Professor, Berlage Institute

Just like Sol Lewitt's precise instructions, architecture reports and specifications can be a mighty representation resource: a design matrix described in rigorous words can warrantee vitality and long-life to a project and its guiding principles.

Keywords: Urbanism - Irak, Persian cities, history of urbanism, planning, survey.

$\mathbf{T}$ he project of founding new cities is again at the center of architectural discourse. In the last decades we have witnessed the rise of numerous cities in many East Asian countries, and the announcement of newly founded cities continues unabated today. In 2001, China's Minister of Civil Affairs acknowledged his ambition to build 400 new cities by 2020 in order to accommodate rural migrants and foster the ongoing process of the country's industrialization.

In the Middle East, the recent urban boom has been twinned by ambitious projects for new cities that have attracted widespread media attention thanks primarily to the involvement of various starchitects. Moreover, the recently celebrated fiftieth anniversary of the inauguration of Brasilia swung attention back towards those often-neglected experiences in the history of modern architecture and planning that for many years historiography has considered as nothing more than utopian failures.

Although it would be necessary to make a distinction between those projects that have been or are able to further a new "idea of the city" and those that are simply replicas of pre-existing urban paradigms by looking at few relevant cases in the history of architecture, analyzing these projects makes it immediately clear that designing a city from scratch is actually not a rare task that few architects might have to confront during their careers, but perhaps the most challenging design exercise, one in which the scope, possibilities and limits of our discipline are pushed to their extremes and where the operative capacity of the instruments of our work is fundamentally put to the test.

The project of the city is an oxymoron -an impossibility in its own terms- in which the role of the architect is necessarily limited to the action of delineating those essential formal, typological or even normative principles that would prove capable of controlling the development of the city over time. First and foremost, the project of the city is, in contrast with the dimension and scope of the endeavor itself, a matter of reduction, restraint and limitation. In The Lettered City, an essay on the power of the written discourse in the formation of Latin American societies, author Angel Rama explores the fundamental role of the "lettered man" in order to understand what he considers to be a crucial aspect of the Latin American colonial city. The main characteristic of the colonial city is not, according to Rama, the application of the square grid as the fundamental settlement principle of the city, but rather the rigor of describing in writing those principles that are capable of guiding the composition of urban space, so that the technical order can therefore reproduce and confirm the social order as established by the project.

The attempt to distil the essential and dispose of the superflu- 
ous is confirmed by another important project for a city, the plano piloto of Brasilia. In the case of the newly built Brazilian capital (1956-60), its architect did not win the competition thanks to the clarity of his drawings but essentially thanks to the text of the competition report -the famous relatorio (1957)- in which the few formal and organizational principles of the city (i.e. the use of the superquadra as the city's main residential solution) were clearly described and as such made available to future builders.

This reductionist attitude is also what characterizes the great city project of Al-Mansur's Baghdad, the mysterious and famous "round city" begun in 762 AD and of which no archaeological trace remains. The plan of the city has been the object of historical reconstructions based upon the few available literary sources the History of Baghdad written by Khatib Al-Badhdadi (d. 1071) and Ya'qubi's Geography- carried out primarily by K.A.C. Creswell, who in his A Short Account of Early Muslim Architecture (1958) provided a first possible interpretation of the plan of the city, and later by Jacob Lassner in TheTopography of Baghdad in the Early Middle Ages (1970). Although Al-Mansur's Baghdad is not the first circular city to have ever been built, it should be considered one of the most remarkable examples of Muslim town planning. The city can generally be described as a ring with a circumference of 16,000 cubits (circa $8.3 \mathrm{~km}$ ), which gives a diameter of 5,093 cubits, or circa $2.6 \mathrm{~km}$ (the cubit is an ancient measurement of length that is approximately equal to the length of a forearm and that Creswell suggests measures 51.8 centimeters). Yet, differently from the circular plans typical of Renaissance thinking, where the circle was used to convey the "social hierarchy desired by the planner, with governing body located at the center and living spaces assigned to respective social strata radiating from the center in concentric circles" (Rama, 1996). Al-Mansur's Baghdad is nothing more than a thick inhabitable structure delimiting a large circular emptiness - the great Rahaba- at the center of which the palace of the Khalif was located adjacent to the mosque. The radicalism of the city does not lie in the deployment of an abstract geometrical figure that, as Creswell suggests, can in fact be found in several other cities in the Muslim world beginning with Assyrian military camps, but rather in the attempt to conceive the possibility of the city through the project of its edge, a thick, multilayered inhabitable fortress that simultaneously contains and organizes residential, defensive and communication functions.

The two main reconstructions of the plan put forward by Creswell and Lassner propose the same organization of the linear circular element. The typical section of the ring is characterized by a series of five concentric walls forming three circular inner roads (indicated as the first, second and third fasil) that run uninterruptedly from one city gate to the other. Four equidistant doors, each named after the city or province towards which it opened, allow entrance to the city and cut through the three fasil, thereby interrupting the continuity of traffic. Besides providing overall accessibility to the city, the four doors organize distribution among the several residential sectors, facilitate interchange among the three fasil and allow penetration of the circular inner courtyard. Each gate is, starting from the outer wall, organized as a linear spatial sequence consisting of the bridge that crosses the ditch running around the city's outer wall, a first courtyard, the two city gateways separated by a narrow corridor, a major long arcade designed for some 1,000 guards, a small courtyard cutting through the third fasil and, finally, an inner wall. The definition of a city through the description of a single component, as witnessed in Creswell's and Lassner's reconstructions, confirms the reduc- tionist attitude necessary for designing a city.

While Creswell believes that at the end of the linear sequence of the gate, after the last vaults, one would have passed out into a court 20 cubits square that led directly to the central square, Lassner suggests that "surrounding the central court were the residences of Al-Mansur's younger children, his servants in attendance, the slaves, the treasury, the arsenal, the diwan of the palace personnel, the public kitchen, and various other government agencies", so that there was a ring of building between the third fasil and the central courtyard (Allan, 1991). The possible addition of a residential ring located towards the inner courtyard confirms the essence of the entire urban project as a simple skeleton of walls that supported the process of the city's formation. The three fasil and the gates represent the major infrastructural elements of the city, supporting and serving the areas dedicated to residential functions and eventual urban growth. The existence of the inner ring is an irrelevant issue, as it could easily be read as the natural outcome of the idea of the city itself - a skeleton around which the urban body develops. The project of Al-Mansur's Baghdad and the possible reconstruction of its plan has therefore never been and will never be fully achieved, for the nature of the city itself is based on the control and design of only a few aspects -the gates, the rituals of entering and moving through the city, the linear walls- while the rest seems to be open to a multiplicity of interpretations.

The drawings that accompany the present text offer few possible developments of this radical city's plan in the attempt to envision the outcomes that these formal principles and this attitude toward design could produce. ARo

Martino Tattara Architect, Università IuAv di Venezia, 2002; Master of Architecture, Berlage Institute Rotterdam, 2005 and PhD, Università IUAV di Venezia, 2008. His theoretical work focuses on the relationship between architecture and large-scale urban design issues. He has completed his PhD with a dissertation centered on Lucio Costa's project for Brasilia and has widely published and lectured on topics related to the project of the city. He is the co-founder of the architectural office Dogma; he currently teaches at the Artesis University College of Antwerp and at the Berlage Institute, where he is also responsible for some of the institute's external projects.

Bibliography

ALLAN, James W. "New Additions to the New Edition". In Mugarnas 8. The Aga Khan Program for Islamic Architecture, Harvard University and Massachusetts Institute of Technology, Cambridge, 1991, p. 17.

CRESWELL, K.A.C. A Short Account of Early Muslim Architecture. Penguin Books, Harmondsworth, 1958

LASSNER, Jacob. The Topography of Baghdad in the Early Middle Ages. Wayne State University Press, Detroit, 1970.

RAMA, Angel. The Lettered City. Duke University Press, Durham, NC, 1996. 